\title{
OPTIMIZAREA MEDIILOR DE CULTURĂ PENTRU MICROPROPAGAREA SPECIILOR DE Actinidia kolomikta MAX ŞI Actinidia arguta PLANCH
}

\author{
Cutcovschi-Muștuc Alina, Trofim Mariana \\ Grădina Botanică Națională (Institut) „Alexandru Ciubotaru”, Chișinău, Republica Moldova \\ e-mail:alinacutcovschi@mail.ru
}

Biotehnologiile moderne bazate pe culturile in vitro sunt cu succes utilizate în diferite faze ale procesului de ameliorare a plantelor. Cultura de ţesuturi este cu succes utilizată în obţinerea plantelor iniţiale perfect sănătoase. Pe parcursul anilor această metodă a devenit o tehnică modernă de multiplicare rapidă a speciilor ce prezintă interes pentri ţară. Plantele s-au dovedit a fi potrivite pentru cultura prin metode biotehnologice in vitro, iar realizările în această direcţie au progresat cu paşi rapizi. Ca obiect final al acestor cercetări este multiplicarea şi propagarea rapidă a plantelor, obţinerea materialului săditor devirozat, crearea genotipurilor cu caractere dorite, și rezistenţa la boli şi la agenţii stresogeni fizici şi chimici.

În ultimii ani dintre plantele netradiționale cercetate în cadrul Grădinii Botanice se studiază 2 specii de actinidie: Actinidia kolomikta Max și Actinidia arguta Planch, fructele cărora sunt cunoscute printr-un conținut înalt de substanțe biologic active, vitamine și antioxidanți. Actinidia este o liană, partea aeriană a căreia poate fi divizată în patru componente: trunchi, ramura principală, ramuri de ordinul I, II, III etc, lăstari.

Pentru inocularea plantelor în cultura in vitro au fost testate şi cerectate explantele ca: meristeme apicale și laterale. Explantele au fost dezinfectate cu anumiţi sterilizanţi chimici, după care a fost posibilă inocularea pe mediile nutritive.

Pentru iniţierea proceselor morfogene ale plantei, în cultura in vitro, în primul rând, este nevoie de selectarea mediilor. Calitatea şi cantitatea regulatorilor de creştere şi a mediului de cultură influenţează dezvoltărea proceselor morfogene al explantelor inoculate.

Pentru dezvoltarea acestor procese a fost selectat mediul MS 100\% și Standarte. Este necesar de a alege corect şi regulatorii de creştere şi este important de menţionat că, procesele regenerative sunt condiţionate de un anumit raport auxine-citochinine, citochinină-citochinină caracteristice pentru fiecare specie de plante în parte. Mediile utilizate au fost cele agarizate cu cantitate diferită de agaragar. Dintre regulatorii de creștere pentru mediul MS $100 \% \mathrm{~s}-\mathrm{a}$ folosit BAP $(0,5 \mathrm{mg} / \mathrm{l})+\alpha$ ANA $(0,25 \mathrm{mg} / \mathrm{l})$, iar pentru mediul Standarte s-au utilizat regulatorii de creștere Zeatin $(1,0 \mathrm{mg} / \mathrm{l})+\alpha$ ANA $(0,02 \mathrm{mg} / \mathrm{l})$. Ambele specii de actinidie au fost inoculate pe mediile date. Principalul parametru este pH-ul care s-a stabilit a fi optim 6,8-7.

Dezvoltarea pe ambele medii s-a făcut observată după o lună. Odată cu dezvoltarea plantulelor pe medii s-a produs formarea masei calusare. S-a constatat că, din meristeme s-a dezvoltat caulogeneza iar la baza inoculului s-a format calusul morfogen. Ca rezultat al cercetărilor efectuate asupra mediilor s-a dovedit că plantele pe mediul Standarte suplinit cu Zeatin, au o dezvoltare mai vertiginoasă formând rizogeneza la baza lăstarului și masa calusară.

În procesul de micropropagare la Actinidia kolomikta s-a observat și o diferență dintre plantele masculine și cele feminine. S-a constatat că, explantele de gen masculin cresc mai repede și cantitatea obținută de la un inocul este mai mare în comparație cu explantele de gen feminin.

Ca rezultat al cercetărilor efectuate s-a constatat că, inoculii eficienţi pentru micropropagarea Actinidiei kolomikta și Actinidia arguta în cultura in vitro sunt meristemele apicale și laterale cultivate pe mediile MS și Standarde suplinite cu regulatori de creștere. 